\title{
MÉXICO Y SUS ALREDEDORES: MONUMENTOS, PAISAJES Y LA DEFINICIÓN DE LA HISTORIA. RELECTURA EN TORNO A LAS COLECCIONES DE PAISAJES Y MONUMENTOS EN MÉXICO
}

Fecha de recepción: 09.04.2020

Fecha de aceptación: 24.09.2020

Resumen: Luego de reconocer los múltiples factores que determinaron el desarrollo de las colecciones de paisajes y monumentos en la tradición cultural, artística y literaria mexicana -los álbumes compuestos y editados por los pintores viajeros (1828-1855), el auge de las publicaciones periódicas, de la vertiente pintoresquista del costumbrismo y el dominio e inclusión de la litografía (1843)-, se estudia México y sus alrededores. Colección de vistas, monumentos y trajes del país (1855). El objetivo es reconocer tanto sus deudas con la tradición así como las reformulaciones y replanteamientos que hace de ella, conjunción de relaciones que la convirtieron en la obra cimera del subgénero de las colecciones de monumentos y paisajes en México. Se busca releer así un(os) texto(s) fundacional(es) de la literatura y la cultura mexicana, para complejizar la comprensión de ese proceso de la historia de la cultura literaria que contribuyó a consolidar discursiva e icónicamente la independencia cultural, mental, de México y el mexicano durante el siglo XIX.

Palabras clave: literatura de viajes, relaciones imagen-literatura, colecciones mexicanas de paisajes y monumentos, costumbrismo mexicano, relaciones historia-literatura

Title: México y sus alrededores: Monuments, Landscapes, and the Definition of History. Rereading of the Collections of Landscapes and Monuments in Mexico

\begin{abstract}
After recognizing the multiple factors that determined the development of collections of landscapes and monuments in the national cultural, artistic, and literary tradition the albums composed and edited by traveling painters (1828-1855), the rise of periodicals, from the picturesque side of costumbrismo and the dominance and inclusion of lithography (1843) - we study México y sus alrededores. Colección de vistas, monumentos y trajes del país (1855), to recognize both its interdependencies as well as its conceptual reformulations and restatements of tradition, which made it the leading work of the subgenre in Mexico. The aim is to reread and, thus, recover a foundational text(s) of Mexican literature and culture, in order to make complex the understanding of this historical and cultural process that contributed to the discursive and iconic consolidation of cultural, mental, and intellectual independence of Mexico and the Mexicans during the nineteenth century.
\end{abstract}

Keywords: travel literature, image-literature relations, Mexican collections of landscapes and monuments, Mexican costrumbrismo, history-literature relations 


\section{COLECCIONES DE PAISAJES Y MONUMENTOS EN MÉXICO: FACTORES CONFLUENTES}

El motivo del viaje ha sido consustancial al desarrollo de la literatura occidental desde sus orígenes. Se constata su presencia tanto temática como composicional en algunas de las obras más representativas de dicha tradición, desde La Ilíada y La odisea, de Homero, y El asno de oro, de Apuleyo, en la antigüedad, pasando por La divina comedia, de Dante, durante el renacimiento, manifestándose también en El Quijote, de Cervantes, en los albores de las épocas moderna y contemporánea. Sin embargo, la literatura de viajes, como género específico que vehicula una particular percepción del mundo con base en una formalización artística concreta, adquirió significado y función particulares a partir del movimiento romántico. Igualmente, desde el siglo XVIII -y como influencia de las literaturas inglesa y francesa sobre todo-, la literatura de viajes había tenido presencia destacada en la tradición en lengua española como formalización artística de la cultura y literatura de la Ilustración que permitía el reconocimiento y descripción crítica de los alcances, límites o contradicciones de individuos y colectividades ${ }^{1}$. Así lo prueban El lazarillo de ciegos caminantes (1775), de Antonio Carrió de La Vandera, o las Cartas marruecas (1789), de José Cadalso. El motivo que lo detona como género específico, el viaje o recorrido, implicaba para el hombre romántico la libertad de acción y movimiento a través de la cual podría conocer e integrarse a ese proyecto universal divino que era el mundo, como proyección de la grandeza y magnificencia de Dios, tal como lo postulaba Víctor Hugo en su "Prefacio" a Cromwell (1827); el tránsito del viajero lo enfrentaban dialécticamente con otros modelos humanos y culturales, a partir de los cuales podía definir y asumir su individualidad histórica y cultural. Hay que subrayar la importancia de la literatura de viajes en el contexto decimonónico de la emergencia de las nacionalidades modernas como enunciados éticos y estéticos fundacionales en el proceso de definición de una cultura y una identidad propias, pues permitían reconocer la fisonomía física y moral, las costumbres y los valores comunes a partir de los cuales se establecían las relaciones del individuo con otros individuos, así como también con el proceso histórico y cultural nacional específico. En síntesis, compartiendo las ansias y el espíritu de su época, el hombre romántico entendió el viaje como detonante de una conciencia histórica y cultural individual y colectiva, a partir de la cual podía darse sentido a los diversos proyectos comunes que daban sustento a las naciones en el marco del capitalismo en ascenso.

Una de las múltiples resoluciones artísticas desarrollada con originalidad por la literatura de viajes durante el siglo XIX fue, precisamente, la de las colecciones de paisajes y monumentos. Vistos esos florilegios visuales y literarios como parte del costum-

\footnotetext{
1 La literatura de viajes es aquella narración epistolar que, por lo general, articulada como enunciado artístico a partir del motivo del viaje o recorrido, daba cuenta de los alcances, límites y contradicciones sociales y culturales de una colectividad. Un papel determinante en la definición y desarrollo de esta tradición lo tuvieron las Cartas persas (1721), de Montesquieu.
} 
brismo pintoresquista ${ }^{2}$, a través del motivo cultural y literario del viaje o recorrido por un país o región, los artistas románticos asumieron que tenían la posibilidad de enfrentarse y reconocer la fisonomía, las costumbres y la idiosincrasia de un pueblo, así como de advertir el grado de crecimiento y maduración de esa sociedad. Todo ello se manifestaba, sostenían, en la existencia de diversos monumentos arquitectónicos representativos de un momento histórico originario y mediante la institucionalización de la vida mediante academias y tertulias literarias, pictóricas, musicales, científicas, históricas, filosóficas. Estas eran entendidas en calidad de manifestaciones de la vida en sociedad, asumidas como indicios del crecimiento moral, intelectual, cultural de la sociedad en la que tenían lugar, al manifestar así su capacidad para diversificar, organizar y coordinar la complejidad alcanzada.

Así lo señaló el narrador romántico pintoresquista Patricio de la Escosura en 1842, al afirmar en la introducción a España artística y monumental, texto iniciador de las colecciones de paisajes y monumentos en la tradición hispánica ${ }^{3}$, que la arquitectura es un "arte cuyos productos son los más duraderos de cuantos se deben á la mano del hombre, y en los cuales la civilización, el poder, la riqueza, la estabilidad y hasta las creencias de los pueblos se reflejan irremediablemente" (Villamil y De la Escosura 1842: 3).

2 El pintoresquismo fue una de las dos vertientes que planteó y asumió el costumbrismo en la tradición literaria hispánica decimonona. A diferencia de la vertiente satírica y crítica representada por Mariano José de Larra, el pintoresquismo, desarrollado sobre todo por Ramón de Mesonero Romanos y Serafín Estévanez Calderón, se dio a la tarea de reconocer empáticamente los arquetipos humanos y culturales que definían y daban originalidad a una cultura específica. En la línea de investigación desarrollada aquí, planteo que, entre las décadas que van de 1840 a 1870 aproximadamente, el costumbrismo pintoresquista fue la resolución artística dominante en México -junto con la novela histórica-, pues permitió a los letrados contribuir en la definición de un proyecto nacional específico ( $c f$. Bobadilla Encinas y Avechuco Cabrera 2020).

3 España artística y monumental. Vistas y descripción de los sitios y monumentos más notables de España fue un texto en tres tomos, dibujado por Jenaro Pérez de Villamil y escrito por Patricio de la Escosura, miembros de la tertulia de "El parnasillo", de Madrid, cuna del romanticismo español. Cada volumen fue publicado en París en 1842, 1844 y 1850, los dos primeros durante el exilio de los artistas en la capital gala, debido a sus diferencias ideológica con el gobierno liberal de Espartero (1840-1843), como una muestra, quizás, de su nostalgia por el suelo natal; en este sentido, el tercer volumen, compuesto durante su regreso a España, sería una especie de conclusión más pintoresca, menos melancólica que los tomos anteriores, lo que se trasunta en la incorporación de un mayor número de escenas costumbristas. La obra fue publicada en una edición bilingüe, en español y en francés, debido tanto a la coyuntura vivencial de los autores -exiliados radicados en Francia, cuyos lectores podrían ser no solo otros desterrados hispanos sino también el público galo- y al hecho de que el francés era la lengua franca de la época.

Los tres tomos de la obra suman en total ciento cuarenta y cuatro litografías e igual número de descripciones literarias de paisajes y monumentos. La historia y crítica de arte lo considera como la colección de vistas de paisajes y monumentos con la cual inicia de este tipo de representación artística en España (cf. Ortega Fernández 2010).

El texto articulado por Pérez de Villamil y De la Escosura inaugura, pues, ese imaginario plástico propio del romanticismo dentro de la literatura y la cultura artística hispana, mediante el cual el arte, la hermandad de la literatura y la litografía, encontraron una resolución ética y estética con la cual participar del proceso de construcción de una identidad histórica. No puede soslayarse el hecho de que, en ese momento, la sociedad española se encontraba inmersa en un proceso de reconfiguración, luego del término de la primera guerra carlista (1833-1840) y los estragos sociopolíticos, culturales e históricos que provocó al alterar el imaginario restauracionista sobre el cual se había sustentado la monarquía y el reino hasta entonces. 
Partiendo de esta certeza, el escritor español otorgaba sentido y trascendencia a las colecciones de paisajes y monumentos, al considerar que

conocer la arquitectura de un pueblo es conocer también al pueblo mismo, al menos en general y con respecto al grado de civilización en que se halla. Ciertamente no basta el estudio de los monumentos, por profundo y aprovechado que sea, para escribir la historia. Enemigos de exageraciones, nos guardaremos de incurrir en esa: pero sostendremos con íntimo convencimiento que sin el auxilio de aquel importante ramo de los conocimientos humanos [esto es, de la arquitectura], jamás podrá formarse cabal idea de la índole, carácter, é ilustración de un estado. (Villamil y De la Escosura 1842: 10, las cursivas son mías)

Tras estos presupuestos pueden reconocerse los ecos de las consideraciones de Madame de Staël en De la literatura y su relación con las instituciones sociales (1800), texto conocido por los escritores e intelectuales mexicanos de la centuria, ya en la versión francesa, ya en la traducción al español que en 1829 realizó la Imprenta de Piller. Así lo prueban las constantes referencias a la autora y sus planteamientos por parte del Conde de la Cortina, Luis de la Rosa, José María Lafragua, Francisco Zarco, entre muchos otros letrados decimonónicos, manifestando así la huella indeleble de Anne-Louise Germaine Necker en la concepción y función de la literatura y el arte en México e Hispanoamérica.

En este contexto, resulta muy revelador lo afirmado por Manuel Payno en su Viaje sentimental a San Ángel, relato de viajes publicado en El Museo Mexicano en 1844, al reconocer que habría pocos lectores mexicanos del siglo XIX que no conocieran ni hubieran visto esos hermosos libros, llenos de grabados finísimos que representan escenas de la naturaleza y de las ciudades de los países más célebres del mundo; cuando ve uno tales libros, decía el narrador costumbrista, es imposible dejar de exclamar " «iOh, qué vista tan sorprendente! ¡Qué cascada tan magnífica! ¡Qué campo tan bello! ¡Si yo viera estas escenas, sería el más feliz de todos los mortales!»" (2007: 40-41). Traigo esto a colación porque las consideraciones de Payno en su particularmente logrado relato de viajes, son un testimonio revelador de la importancia que tenían ya dentro de la tradición cultural y literaria mexicana las colecciones de paisajes y monumentos. En aquellos tiempos tan tempraneros del proyecto de la literatura mexicana, el escrito en cuestión buscaba reforzar a nivel cultural la emancipación política hacía poco alcanzada, en 1821.

En esa época en que literatura eran todas las expresiones humanísticas escritas de la cultura -historia, derecho, filosofía, poesía, entendida esta última como campo cultural, no como manifestación genérica (cf. Gunia 2008, Urrejola 2011)-, dichos álbumes cumplían la función de socializar imágenes discursivas y plásticas específicas, en torno a la supuesta esencia del hombre y de los espacios nacionales que se estaban perfilando. Debe recordarse que, en las décadas precedentes, las colecciones de tipos, paisajes y monumentos se habían ido definiendo como un enunciado o texto artístico bivocal. En tal orden de cosas, dicho enunciado o texto vino a ser conformado, por un lado, por una parte escrituraria determinada mediante diversos recursos, licencias y perspectivas poéticas -topografía, lirismo, emotivaciones, plasticidad rítmica- y, por otro, mediante una parte plástica, litográfica específicamente, que apostaba por representar icónica o visualmente al hom- 
bre y al espacio mexicanos que se redefinían en el nuevo contexto independentista. Esto último se ejecutaba a partir de técnicas, ángulos y enfoques novedosos -que incluían panorámicas, estructura en dos planos, visión en diagonal ascendente-.

En este contexto, es particularmente revelador el trabajo de pintores letrados, europeos sobre todo, como el italiano Claudio Linati, quien compuso y editó Trajes civiles, militares y religiosos de México en Bélgica en 1828; el alemán Karl Nebel, autor de Viaje pintoresco y arqueológico a la parte más interesante de México, publicado en París en 1836; el francés Jean-Frederic Waldeck, quien ilustró e imprimió Viaje pintoresco y arqueológico a la provincia de Yucatán entre 1832 y 1834, en la capital francesa en 1838; los ingleses Daniel Thomas Egerton, que publicó Vistas de México. Serie de doce platos coloridos ejecutados por sí mismo, acompañados con una corta descripción, en 1840, Frederick Catherwood, autor de Incidentes de viajes a Centroamérica, Chiapas y Yucatán, texto editado en 1843, y John Phillips y Alfred Rider, quienes publicaron México ilustrado con veintiséis dibujos, con descripciones impresas en inglés y español, en 1848, volúmenes editados en Londres; el alemán Johann Moritz Rugendas, quien recopiló sus trabajos de las décadas previas en Paisajes y tipos de México, publicado en Alemania en 1855, entre varios otros como Pharamond Blanchard o Karl Sartorius. Todos ellos no solo representaron visualmente la realidad nacional, sino que también formalizaron de manera literaria las imágenes del hombre y de la realidad cultural y natural que percibían, configurando así dichas colecciones como enunciados o textos bivocales, que articulaban un significado sobre el hombre y el mundo mexicanos a partir de la interrelación transversal de la literatura y la plástica. Es pertinente añadir que se reconoce y asume un antecedente pionero y modélico importantísimo en Alejandro de Humboldt y su Viaje a las regiones equinocciales del nuevo continente, escrito en colaboración con Aimé Bonpland entre 1799 y 1804, texto publicado en la capital gala en 1807, además de que el aristócrata alemán se convirtió en una especie de mecenas para artistas como Nebel y Rugendas, así como lord Kingsborough lo fue para Waldeck.

De esta manera, todos esos textos de los pintores viajeros, compuestos a partir de las expectativas cognitivas y de los imaginarios éticos y estéticos de los artistas extranjeros -el pintoresquismo costumbrista de Nebel, el exotismo orientalista-egipticista de Waldeck-, fueron conocidos y, lo más importante, tuvieron un impacto decisivo entre los artistas plásticos y literarios nacionales y sus receptores. Dichas obras ayudaron, pues, a crear un imaginario y una conciencia propia, nacional, entre los mexicanos recién emancipados de España. Cuestión que tuvo su trasunto en que los artistas y escritores mexicanos, que seguían describiendo y explicando el mundo a partir de los códigos y percepciones de la antigua metrópoli (cf. Martínez 1955, Bobadilla Encinas y Avechuco Cabrera 2020), se volcasen en una serie de esfuerzos ingentes por articular una imagen, un discurso y unos valores propios, que dieran sentido cultural concreto a la autonomía consumada en 1821.

En este contexto, es importante señalar que, al menos entre los diecisiete años comprendidos entre 1826, cuando Claudio Linati introdujo en México la técnica y las prensas litográficas, y 1843 aproximadamente, cuando los artistas gráficos del país adquirieron el dominio del procedimiento, casi la totalidad de las colecciones de tipos, paisajes y monumentos sobre México y los mexicanos fueron concebidas y editadas por artistas extranjeros, quienes las imprimían en Europa. Por un lado, durante ese periodo, 
los artistas e impresores mexicanos (con honrosas excepciones, por supuesto) emprendieron la labor de apropiarse y dominar el manejo de la litografía, periodo de aprendizaje que alcanzaría su culmen alrededor de 1843 precisamente, cuando las imprentas y casas editoriales mexicanas pudieron formar ya los recursos humanos capaces de ejecutar artística y técnicamente las estrategias litográficas (cf. Aguilar Ochoa 2007). Asimismo, a partir de esa década, comienzan a instalarse en México diversas casas editoriales francesas -Massé y Decaén, Fourier, Michaud- que incentivaron la producción y reforzaron la ejecución de la litografía en México (cf. Pérez Salas 2009).

Hay un consenso en la historia del arte mexicano en considerar que la primera colección de paisajes y monumentos realizada en el país fue Monumentos de México tomados del natural, de Pedro Gualdi (1841). Si bien dicha obra fue compuesta y realizada por el artista de origen italiano durante una estancia de doce años en el país ${ }^{4}$, tuvo la capacidad y sensibilidad de captar y representar gráficamente la grandeza monumental de plazas y edificios civiles y religiosos de la capital, tanto como de articular un discurso escriturario y plástico capaz de expresar una percepción asombrada y orgullosa de la realidad arquitectónica y cultural representada.

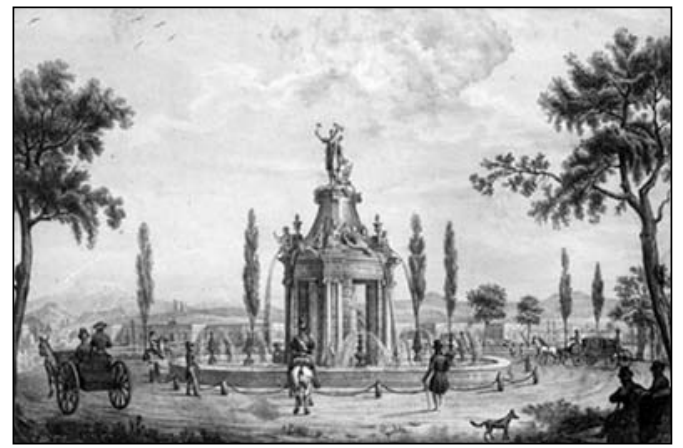

Fig. 1 "Paseo de la independencia". Fuente: Monumentos de México tomados del natural (1841). Reproducidas con base en las normas de uso del Repositorio de la Secretaria de Cultura de México.

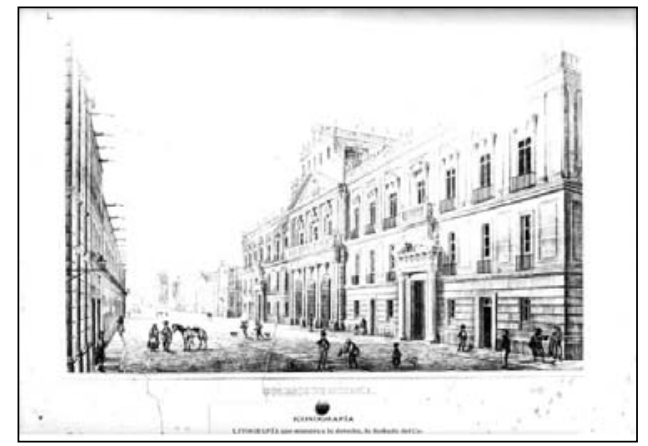

Fig. 2 “Colegio de Minería”. Fuente: Monumentos de México tomados del natural (1841). Reproducidas con base en las normas de uso del Repositorio de la Secretaria de Cultura de México.

Compuesta plásticamente a partir de la técnica europea de "los panoramas", esto es a partir de la captación del horizonte o escena citadina desde una perspectiva circular, en la cual "el espectador se ubicaba en el centro de la sala y daba la impresión de contemplar su ciudad [o el espacio representado] desde las alturas, como si se hubiera ubicado en la cúspide de una torre" (Pérez Salas 2017: 103-117), Monumentos de México tomados

\footnotetext{
4 Pedro Gualdi (1808-1857), pintor formado en la Academia de Artes de Milán, fue escenógrafo de la compañía italiana de ópera, con la que llegó a México en 1838; permaneció en el país alrededor de doce años. Colaboró con algunas de las casas editoriales e imprentas nacionales y extranjeras -como las de Massé, Decaén, Michaud, Cumplido, Segura-, contribuyendo así al desarrollo de la litografía en México. Entre 1851 y 1857 radicó en Nueva Orleans, donde murió.
} 
del natural se asumió dentro del contexto histórico, cultural y artístico mexicano como la primera colección de paisajes y monumentos que expresó genuinamente y sin exotismos el paisaje de la ciudad y la riqueza y complejidad alcanzada por la cultura nacional. Independientemente de la extranjería del pintor, sus descripciones literarias fueron enunciadas entusiastamente por un narrador mayestático que, en primera persona del plural, habla de "nuestros" monumentos y plazas, de "nuestra" historia y "nuestra" cultura, expresando así tanto la empatía como la identificación del narrador con su objeto de interés, esto es, con la arquitectura, la cultura y la historia de México y los mexicanos ${ }^{5}$.

A esto habría que sumar el hecho de que en casi todas las doce litografías del álbum se encuentran representados los diversos sectores conformadores de la sociedad y cultura mexicana de la época, lo que hace al texto particularmente dinámico y dialéctico, pues lo usual era captar pintorescamente la vida de los sectores populares considerados representativos del temperamento y la idiosincrasia nacional; se echaba mano a arquetipos culturales característicos de los conglomerados nacionales, como sucede en España artística y monumental (1842, 1844, 1850), en donde beatas, majos, gitanas y pastores rezan, bailan fandangos y jotas, toman vino en botas o arrean manadas de ovejas. El texto de Gualdi, en cambio, fue más abarcador y, por eso, más representativo de la complejidad de la sociedad mexicana; incorporó la dinámica diversidad social y cultural de México y el mexicano ${ }^{6}$, donde conviven chinas y léperos, vendedoras y aguadores, sí, pero también indios, criollos y mestizos, burgueses, obreros y artesanos. Quizás por ello el texto resultó tan importante e influyente dentro de la literatura y el arte nacionales, al permitir la identificación de casi la totalidad de los personajes del gran teatro de la vida en México. A reserva de desarrollarlo más adelante, habría que señalar que estas características son indicios que permiten reconocer la influencia definitiva que ejerció Pedro Gualdi sobre los letrados y litógrafos mexicanos del periodo comprendido entre 1840-1870 al menos. Asimismo, pueden advertirse varias de las características y funciones de su obra en planteamientos bivocales posteriores de algunos de sus discípulos y contemporáneos, como Casimiro Castro, J. [Juan o José ¿?] Campillo, Hesiquio Iriante o G. [Guadalupe ¿?] Rodríguez.

En este marco hay que emplazar el paulatino cultivo que comienzan a tener los enunciados o textos bivocales en los periódicos y revistas culturales y literarios portavoces o continuadores de los planteamientos de la Academia de Letrán por mexicanizar la literatura; se buscaba con ello contribuir en la emancipación cultural, mental de México y el mexicano ${ }^{7}$.

\footnotetext{
Es interesante observar cómo en la primera colección de los tipos mexicanos, la de Linati (1828), los personajes y escenas son descritos desde una tercera persona del singular que marca una distancia entre el narrador y su objeto de la representación artística, los mexicanos precisamente, lo que ayuda a entender la mirada pintorequista y paternal desde la que el narrador realiza sus descripciones y valoraciones.

6 Soslayando, eso sí, las tensiones y contradicciones de la vida mexicana, al plantear una coexistencia pacífica de las distintas clases y razas, que, por lo demás, seguramente le imponía la perspectiva pintoresquista desde la cual representaba el mundo.

7 La importancia de la Academia de Letrán en México radica en sus afanes por configurar un discurso formal y temático propio, mexicano, y en haber reconocido en los órganos periódicos de expresión un vehículo para la socialización de sus postulados ( $c f$. Ruiz Castañeda 1999, Perales 1957, Castro y Curiel 2010).
} 
Luego del dominio de la técnica litográfica alcanzado por los impresores y técnicos mexicanos en los primeros años de la década de 1840 ( $c f$. Aguilar Ochoa 2007), comenzaron a ser publicados en los principales órganos de expresión periódica diversos cuadros costumbristas; cuéntense como ejemplo los de publicaciones como El Museo Mexicano, la Revista Científica y Literaria de México, el Álbum Mexicano, entre varias otras. Prevaleció al principio la representación de ciertos tópicos en lo tocante a tipos culturales y sociales mexicanos para, a finales del mismo decenio -en el corto lapso de siete u ocho años-, pasar a centrarse en vistas de paisajes y monumentos. Las vistas de monumentos realizaron la síntesis dialéctica de la tradición previa: al apropiarse e integrar el retrato de los tipos culturales y sociales mexicanos, enriquecieron y dinamizaron la escena de manera semejante a como lo había hecho Gualdi en Monumentos de México-, señalamiento que cuantifica con precisión Carolina Benavides (2007).

Por supuesto, hay otros factores que pueden explicar el auge de los cuadros costumbristas de paisajes y monumentos por sobre los de tipos; por ejemplo, la difusión que tuvo en México la edición de los dos volúmenes de la revista cultural y literaria España Pintoresca, Artística, Monumental, Literaria y de Costumbres $(1843,1844)$. Esta publicación mexicana diseñada a partir del modelo del madrileño Semanario Pintoresco Español (1836-1857), portavoz del pintoresquismo peninsular- dio a conocer entre escritores y lectores nacionales poesía, narrativa, biografía y, en general, artículos misceláneos de las bellas letras, compuestos por los más renombrados costumbristas de la tradición peninsular: Mesonero Romanos, De la Escosura, Espronceda, Larra, entre muchos otros.

Jefferson Rea Spell considera que la revista editada en la imprenta de Vicente García Torres "dió un considerable impulso al movimiento costumbrista [nacional], aunque no contuviera artículos de esta clase escritos por mexicanos. En él se reprodujeron un gran número de artículos españoles [pintoresquistas] que aparecían en las revistas de la Península en fechas anteriores" (1938: 8). En consecuencia, tanto el movimiento costumbrista mexicano como el pintoresquismo español constituyeron modelos a seguir para los narradores nacionales. Coincido totalmente con el estudioso estadounidense, pues sus señalamientos ayudan a explicar el hecho de que la primera etapa del costumbrismo en México, desarrollada entre 1840 y 1870 aproximadamente, estuviera dominada por la perspectiva pintoresquista: este predominio ayudó a articular un discurso histórico y cultural identitario, un conjunto de enunciados, valores e imágenes a partir de los cuales se le dio sentido, representatividad y trascendencia al proyecto de nación que se definía entonces. En este contexto, los textos individuales y las colecciones pintoresquistas de tipos y escenas, de paisajes y monumentos, adquieren un significado y función fundacional en nuestra tradición, articulación que marca diferencia con el enfoque y actitud crítica que al menos en esa época tenían las mismas realizaciones en una de las vertientes costumbristas de la tradición española, la representada por el recientemente fallecido Mariano José de Larra y sus discípulos.

Me he detenido en comentar la función y características de esta publicación en México por dos razones. En primer lugar, porque el título de la revista establece una intertextualidad clara y directa con el de la obra casi homónima que en París editaban desde un año antes, a partir de 1842, Jenaro Pérez de Villamil y Patricio de la Escosura -España Pintoresca, Artística, Monumental, Literaria y de Costumbres el de la publicación periódica, España artís- 
tica y monumental el de los volúmenes-, lo que es un indicio del conocimiento que había en México sobre la tradición que definían y fundaban los artistas tertulianos de "El parnasillo" de Madrid. En segundo lugar, porque en la anónima "Introducción" al primer volumen de la revista $(1843)^{8}$, en un extenso listado de los motivos con los que se explicaba la importancia y novedad que ofrecían las revistas culturales y literarias al público moderno -sobre todo la revaloración de la estética romántica-, se destaca en especial que

descuellan por su amenidad, por su utilidad y por sus atractivos las [obras] que se dedican especialmente a las antigüedades [...] Efectivamente es una cosa muy natural que cada pueblo procure conservar los monumentos que le recuerdan la gloria y grandeza de sus padres [, de sus orígenes]. [Los artistas románticos] nos dan ejemplo de su veneración a sus monumentos nacionales, por el amor con que los ensalzan e imprimen sus elogios y los hacen circular. (1843: 4, las cursivas son mías)

Creo advertir en esta afirmación un reconocimiento a los motivos y razones por los que hacía apenas un año antes el pintor Jenaro Pérez de Villamil y el narrador Patricio de la Escosura habían introducido e inaugurado el subgénero de las colecciones de paisajes y monumentos en la tradición cultural y artística española en particular, hispánica en general. Como señalé antes, en la parte escrituraria de España artística y monumental, el escritor pintoresquista español había establecido que el significado y función de las colecciones de paisajes y monumentos radicaba en el hecho de que conocer las edificaciones antiguas, pertenecientes a específicos y señalados momentos de la historia de una nación, permitía conocer al pueblo mismo, "la índole, carácter, é ilustración de un estado" (Pérez Villamil y de la Escosura 1842: 10), pues los monumentos son un testimonio "de la civilización, el poder, la riqueza, la estabilidad y [donde] hasta las creencias de los pueblos se reflejan irremediablemente" (3). En este imaginario histórico y cultural que contribuyeron a dar a conocer en México la revista España Pintoresca, Artística, Monumental, Literaria y de Costumbres y la primera colección de paisajes y monumentos del mundo hispánico, España artística y monumental, resulta lógico el hecho de que, dentro del costumbrismo mexicano desarrollado entre 1840 y 1870, adquirieran una función protagónica las resoluciones artísticas de los textos bivocales de paisajes y monumentos, apropiándose y refuncionalizando la de los tipos, como certeramente señala Carolina Benavides (2007).

Establecido esto he de continuar indicando que, inicialmente, los artículos y los textos bivocales literario-litográficos que aparecieron publicados en los periódicos y revistas de la época fueron resultado de una práctica individual, pues, dado el medio de expresión periódica en el que se dieron a conocer y la formulación pionera y/o primeriza de su praxis, los narradores y litógrafos mexicanos realizaban su obra de manera independiente, sin visualizarse ni formar parte de un proyecto ético y estético conjunto y sistemático. Tal consideración es reforzada por el hecho de que aunque se compusieron colecciones de paisajes y monumentos cuyo tema era la realidad cultural y natural mexicana

\footnotetext{
8 Aunque en España Pintoresca aparece sin firma, esa "Introducción" reproduce la que realizó Pablo Piferrer a su Recuerdos y bellezas de España (1839-1865), el texto bivocal representativo del medievalismo romántico catalán.
} 
durante la década de 1840, todas esas obras colectivas siguieron siendo de autoría extranjera y publicadas en casas editoriales parisinas, londinenses o alemanas -así lo prueban los trabajos de Egerton, Catherwood, Philips y Rider, Blanchard, Sartorius-. Fue hasta que Urbano López publicó Álbum pintoresco de la República Mexicana a finales de esa década ${ }^{9}$, bajo el sello de la Estampería de Jules Michaud y Thomas aunque impreso en la casa Lemercier de París, que se edita un álbum o colección de paisajes y monumentos en México por un artista nacional. Con todo, hay que reconocer que las láminas son una burda amalgama de textos plásticos del Viaje pintoresco y arqueológico, de Carlos Nebel, y de Monumentos de México, de Pedro Gualdi, superposición grosera de imágenes que altera la simetría y equilibrio del volumen de los cuerpos y las edificaciones representados por los enunciados bivocales originales ${ }^{10}$.

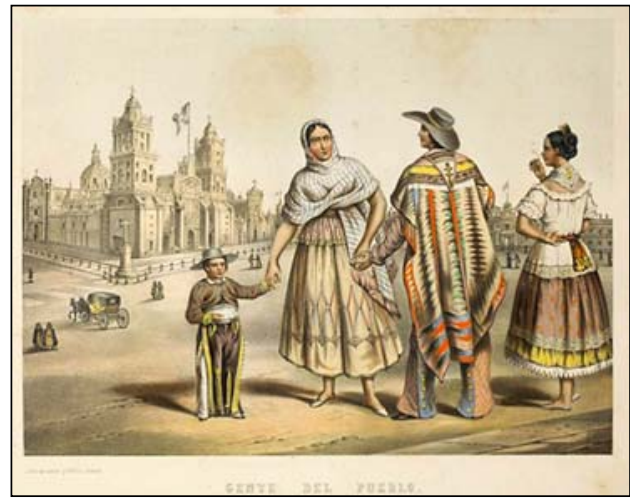

Fig. 3 "Gente del pueblo. Plaza mayor y catedral de México". Fuente: Álbum pintoresco de la República Mexicana (¿1850?). Reproducidas con base en las normas de uso de la Biblioteca Nacional de España.

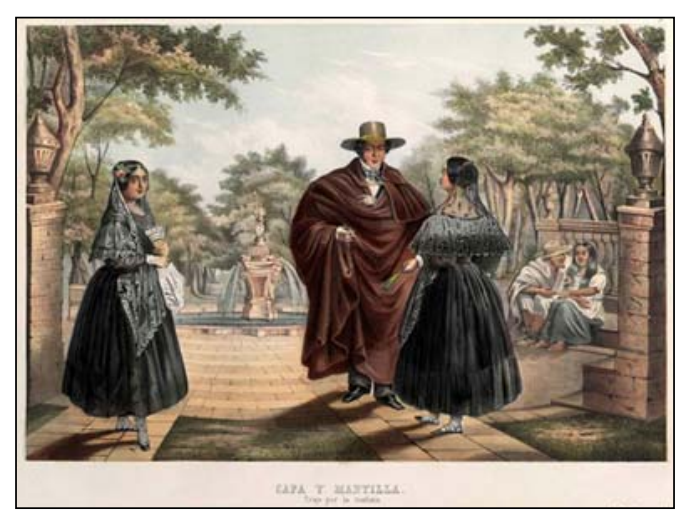

Fig. 4 "Capa y mantilla. Traje por la mañana". Fuente: Álbum pintoresco de la República Mexicana (¿1850?). Reproducidas con base en las normas de uso de la Biblioteca Nacional de España.

Tomando en cuenta la especificidad de la tradición de textos bivocales de paisajes y monumentos mexicanos -amplia temáticamente y con múltiples realizaciones extranjeras que contrastan con las escasas producidas por nacionales-, llama la atención de manera particular la publicación de México y sus alrededores. Colección de vistas, monumentos y trajes del país en 1855. En tal orden de cosas, no parece arriesgado considerar que esta obra -que a reserva de otros datos puede considerarse la tercera formalización hecha en México por un mexicano-, entró en diálogo con aquella tradición e imaginario -tanto nacional como extranjero-, ejecutando una transformación de sus alcances y dando forma a un texto señero, de los mejor logrados del subgénero en México.

\footnotetext{
9 Aunque no se cuenta con el dato preciso, se estima que fue publicado entre 1845 y 1850.

10 Si bien muchas de las láminas que componen Álbum pintoresco de la República Mexicana son dibujos originales firmados por dibujantes franceses como Frederic Lehnert y Fernando Bastin, también es cierto que la mayoría de los dibujos que rubrica Urbano López son una copia y superposición de dibujos cuyos autores reconocidos y probados son Carlos Nebel y Pedro Gualdi.
} 


\section{MÉXICO Y SUS ALREDEDORES, REFUNCIONALIZACIÓN DE LOS PRESUPUESTOS DEL SUBGÉNERO}

Una de las páginas más bellas (si no es que la más bella) artística, ética y estéticamente hablando de la literatura y el arte mexicanos del siglo XIX está representada por la hermandad de la literatura y la plástica que determina la composición de México y sus alrededores. Colección de vistas, monumentos, paisajes y trajes del país. El volumen fue publicado originalmente entre 1855 y 1856, siendo reimpresas y comercializadas las láminas entre 1857 y 1858 de manera independiente; tuvo una segunda edición aumentada en 1864, en el marco del Segundo Imperio Mexicano que, con correcciones sobre todo litográficas, ha sido la versión más conocida: ello es indicador de la importancia y trascendencia de la obra, pues fue uno de los esfuerzos del sistema imperial encabezado por Maximiliano de Habsburgo para proyectar la original belleza y pujanza del efímero reino; la última edición de la obra durante el siglo XIX fue en 1869, en la que aparecieron coloreadas todas las láminas. Cabría señalar que en 1885, veintiún años después de la segunda edición, muchas de las láminas, descontextualizadas y desprovistas ya de la parte literaria, aparecieron publicadas nuevamente, ahora con el nombre de Álbum mexicano, bajo el sello de la Antigua Litografía Debray de la Ciudad de México, con una calidad, considero, muy pobre, pese a estar firmadas por Casimiro Castro, pues los retoques de Gallice, Pérez y J. Álvarez rebajaron el valor plástico de las vistas.

En su primera versión, la colección de paisajes y monumentos estuvo conformada por treinta y cuatro descripciones literarias y cuarenta litografías, clasificadas en treinta y cuatro vistas de paseos y monumentos, cinco representaciones de trajes y tipos y una museográfica, además de un plano general de la Ciudad de México; en la segunda edición, por cuarenta y un descripciones y cuarenta y tres cuadros plástico-literarios más ${ }^{11}$. La obra fue publicada bajo la dirección de Joseph Decaén, el impresor francés radicado en México desde mediados de la década de 1830, con dibujos litográficos de cuatro de los más prestigiados e influyentes litógrafos de la época, Casimiro Castro, J. [Juan o José ¿?] Campillo, G. [Guadalupe ¿?] Rodríguez y Luis Anda ${ }^{12}$, con artículos descriptivos literarios de Marcos Arróniz, José María Roa Bárcena, Florencio María del Castillo, José Tomás de Cuéllar, Francisco González Bocanegra, José María González, Hilarión Frías y Soto, Luis Gonzaga Ortiz, Manuel Payno, Anselmo de la Portilla, Vicente Segura Argüelles, Francisco Zarco y Niceto de Zamacois.

La importancia histórica, cultural y literaria de la obra radica en el hecho de que reúne las que, a la postre, se han convertido en las más icónicas imágenes del México

11 Cabe señalar que entre la primera y la segunda edición los dibujantes y litógrafos realizaron ajustes en cuando a colores y ángulos de la representación, así como la inclusión de personajes y situaciones que actualizaban lo escenificado. Dado que el interés de este trabajo se centra en la interrelación palabra/ imagen, solo enuncio esos ajustes o replanteamientos, mismos que estudia acuciosamente Liliana Astrid Ocampo en "La Ciudad de México en las litografías de Casimiro Castro, 1855-1864" (2012).

12 He visto apellidado de manera indistinta al litógrafo ya como "Auda", ya como Anda". A reserva de una argumentación que muestre lo contrario, me decanto por el segundo nombre, pues al parecer el primero obedece a un equívoco producido por la impresión invertida de las letras. 
decimonono, como son "La plazuela de Guardiola", "La Fuente de la Tlaxpana", "La catedral de México", "Trajes mexicanos" o la sin par y romántica "Las Cadenas en una noche de luna".

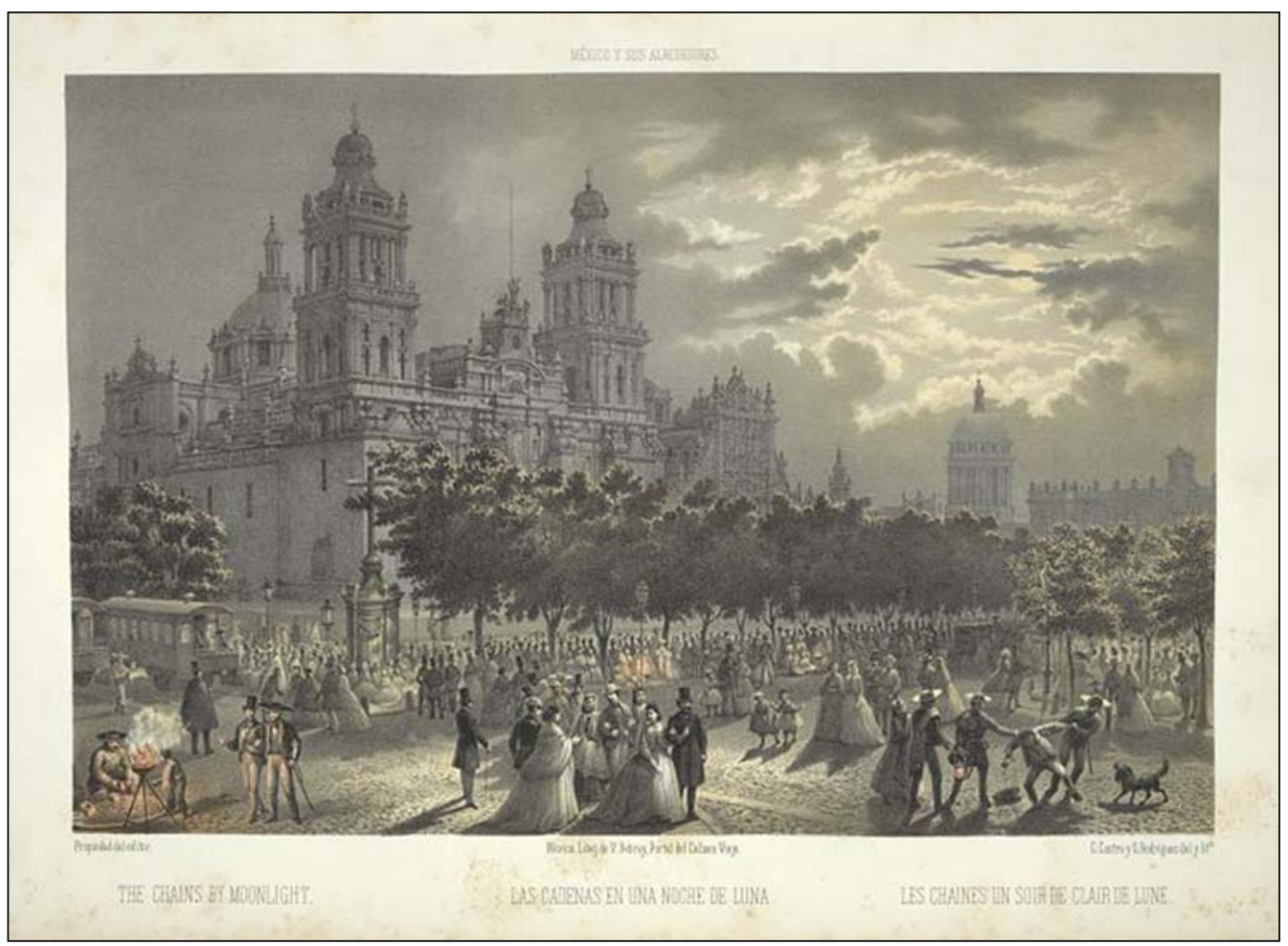

Fig. 5 “Las Cadenas en una noche de luna”. Fuente: México y sus alrededores (1869). Reproducidas con base en las normas de uso de The New York Public Library.

Todas esas ilustraciones reúnen en imágenes tanto literarias como plásticas la imponente grandiosidad de los principales monumentos de la Ciudad de México y de lo que entonces eran algunas de sus zonas conurbadas (San Ángel, Tlalpan, Tacubaya, Ixtacalco, entre otras), encuadradas en un marco natural magnífico y sublime. Retomando el recurso que había popularizado en México Pedro Gualdi en sus Monumentos de México, México y sus alrededores se compone visualmente a partir de la técnica de los panoramas, renovados el recurso y el punto de vista que posibilitaba por el hecho de que en esa época surgieron y se pusieron de moda los ascensos en globos aerostáticos en el país, primero por el interés de Benito León Acosta en 1842, posteriormente con el impulso que les dio la inquietud de Joaquín de la Cantolla y Rico a partir de 1863. La importancia de este hecho está reconocida y representada composicionalmente en el álbum diseñado y dirigido por Decaén, dado que varias de las láminas así lo señalan en títulos y dibujos, como lo revelan textos bivocales como "La Ciudad de México tomada en globo desde el noroeste", "La Villa de Guadalupe tomada en globo el 12 de diciembre", "La Alameda de México tomada en globo" o "El pueblo de Ixtacalco tomado en globo". 


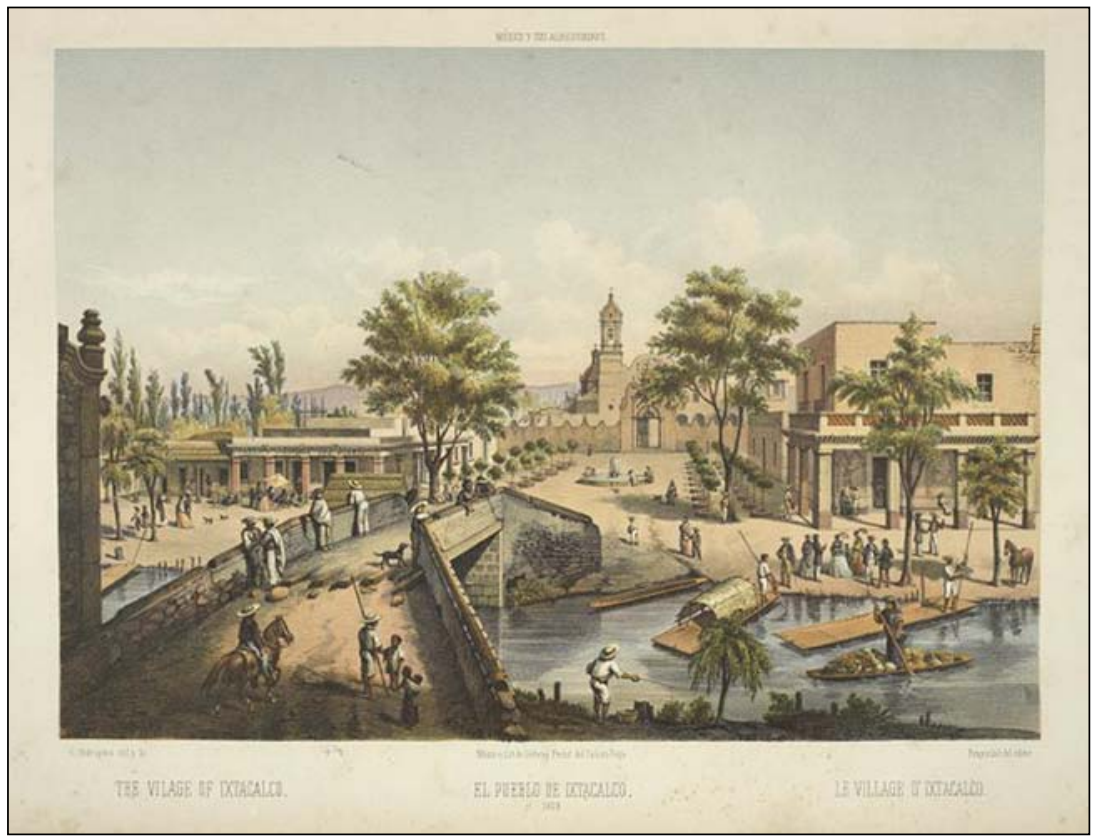

Fig. 6 "El pueblo de Ixtacalco tomado en globo". Fuente: México y sus alrededores (1869). Reproducidas con base en las normas de uso de The New York Public Library.

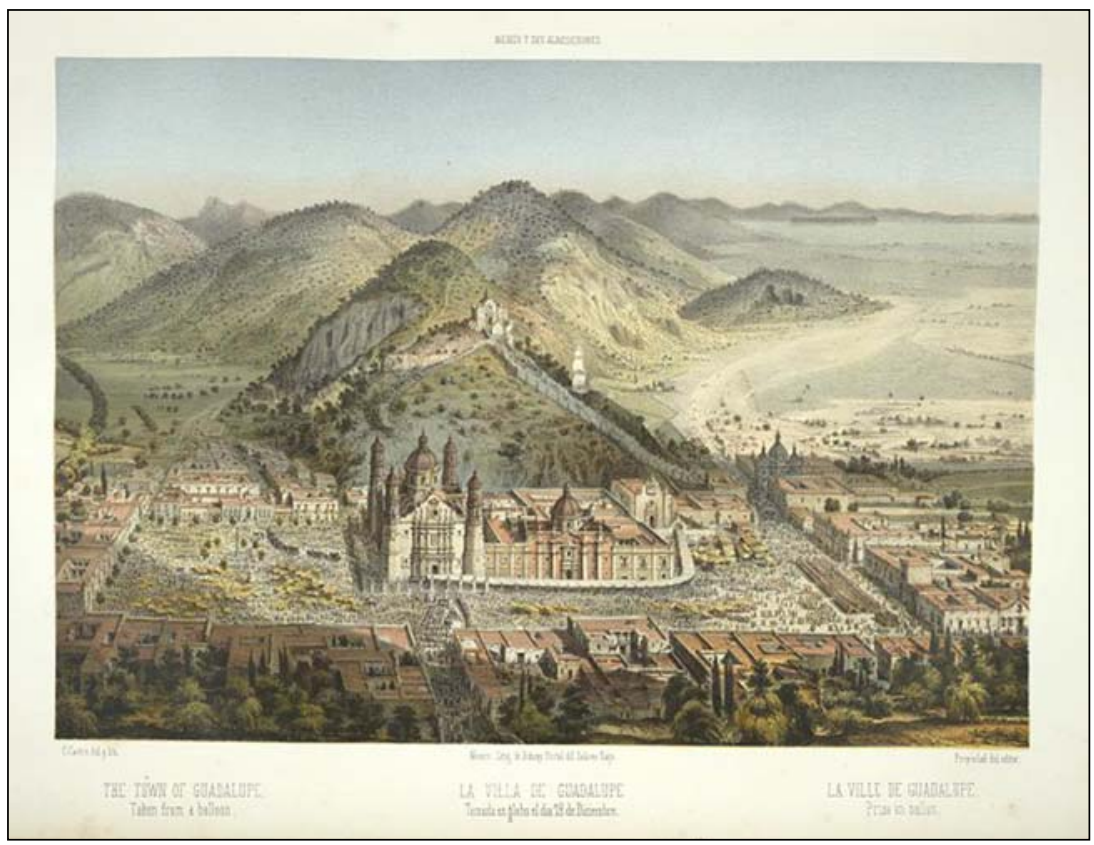

Fig. 7 "La Villa de Guadalupe tomada en globo el 12 de diciembre”. Fuente: México y sus alrededores (1869). Reproducidas con base en las normas de uso de The New York Public Library. 
Se considera que

las técnicas empleadas en el álbum [...] siguieron los parámetros de la época: litografías a dos colores o duotono lograda a partir del uso de dos piedras, una color sepia oscuro o negro y otra color ocre claro que resaltaba los detalles tales como las nubes o la indumentaria de los personajes. Con el tiempo [en las sucesivas reimpresiones y ediciones de 1857, 1864 o 1870] se fueron agregando colores que requirieron la utilización de otras piezas, una por cada color, así como una piedra azul para atenuar el cielo y el agua, y otra verde para matizar la vegetación. (Ocampo 2012: 67)

Lo más importante fue que México y sus alrededores se diseñó e imprimió en sus dos primeras ediciones como un volumen que obedecía a un plan y una estructura significativa determinadas, integrado por diversas imágenes escriturarias e icónicas de lo que se asumía y entendía como edificaciones exponentes del alto grado de desarrollo de la cultura mexicana, las que, por lo demás, hay que reconocerlo, habían sido fijadas ya dentro del imaginario cultural, artístico y literario por escritores y litógrafos anteriores como Nebel, Rugendas o Gualdi. A esto habría que sumar el hecho de que la colección se planteó como un ejercicio colectivo, resultado no del trabajo aislado de un escritor y un litógrafo en un texto misceláneo, sino de una praxis conjunta y colectiva que integraba esfuerzos para testimoniar la autonomía cultural e histórica de México y los mexicanos.

Casi como leyenda en torno a la génesis de la obra, se dice que, en el proyecto inicial, el volumen abriría con el texto bivocal titulado "La Fuente de la Tlaxpana", cuya parte literaria había sido elaborada por Marcos Arroniz y la litográfica por Castro y Campillo. Sin embargo, a punto de empezar los trabajos de impresión, el director del proyecto, Joseph Decaén, decidió que el artículo con el que comenzara el volumen fuera "La Fuente del Salto del agua", escrito por Francisco Zarco con litografía de Luis Anda y Casimiro Castro. La ordenación cambió después de la edición de 1864, despojando en mucho del sentido y función iniciales al texto, pues se perdió o diluyó al menos la exposición de los motivos y justificantes que determinaron su composición y realización.

Mientras el texto bivocal de Arróniz, Castro y Campillo expresaba plenamente la intención y enfoque pintoresquista del volumen, el enunciado literario de "Fortún" -pseudónimo de Zarco- establecía, además, el sentido y función de las colecciones de paisajes y monumentos en México. Esto se conseguía a partir de establecer que, ante la falta de una identidad cultural nacional y ante la inexperiencia colectiva para visualizarse e integrarse en un proyecto común debidas a los trescientos años de coloniaje con España, México era un país sin tradiciones ni valores que lo cohesionaran:

No somos aztecas, no somos españoles; raza bastarda de las dos, tenemos la indolencia de la una, la arrogancia de la otra; pero aun no constituimos una raza propia, distinta de las demás con cualidades, buenas o malas. Pueblo de ayer, sin tradiciones, sin grandes recuerdos, nuestra historia de pocos años es la crónica de la inexperiencia, de la locura y de la discordia y falta a nuestros acontecimientos más notables ese prestigio fascinador de la distancia que dan a los hombres y a las cosas los montones de siglos que se interponen entre las generaciones. (Zarco 1855: 4, las cursivas son mías) 


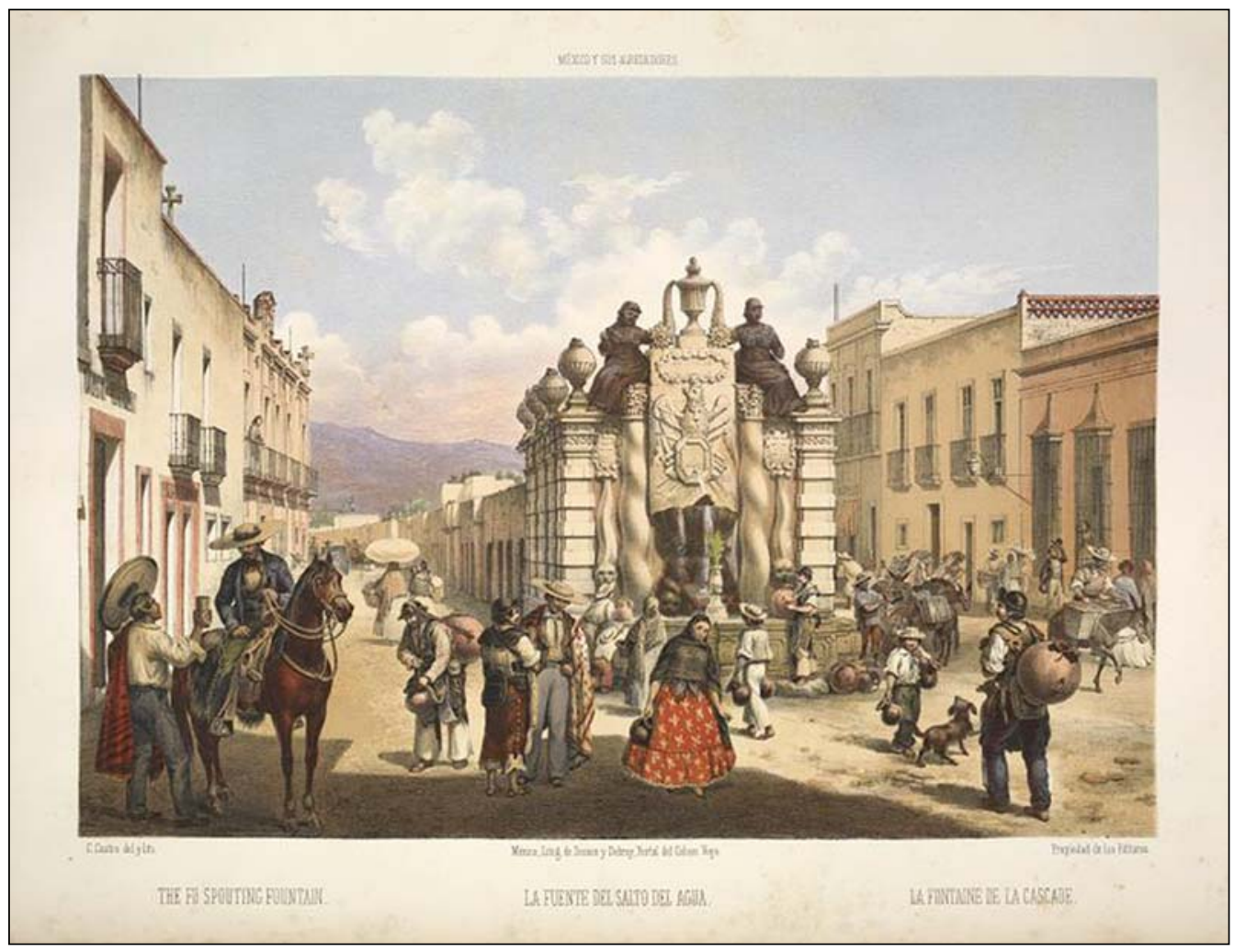

Fig. 8 "La Fuente del Salto del Agua”. Fuente: México y sus alrededores (1869). Reproducidas con base en las normas de uso de The New York Public Library.

Se plantea así desde el principio que el problema cultural de México y el mexicano es la falta de una historia propia, pues implícitamente y sin problematizarlo se ubicaba al mestizo y su historia como el centro de toda reflexión acerca de la identidad; esto se explicita en el texto a partir de una serie de isotopías que reconocen en casi todos los enunciados literarios conformadores de México y sus alrededores que "no existen datos o fuentes históricas" o que "se han perdido los documentos históricos" que explican el sentido fidedigno de tal o cual edificación o monumento. Esto constituía un debate tácito con el Nacionalismo criollo, que hasta entonces había campeado en la cultura y la literatura mexicana naciente ${ }^{13}$; se trata de la misma polémica que tendría su resolución

13 Señala David Brading (1997) que después de la consumación de la independencia en 1821, los criollos se hicieron con el gobierno y conducción del país, manteniendo mucho del orden y los privilegios de casta del periodo colonial. Luego de tres lustros de pasmo, los letrados mexicanos reaccionaron y se dieron a la tarea de alcanzar ahora la emancipación cultural, mental, intelectual y literaria de México, con la finalidad de dar trascendencia a la independencia política (cf. Martínez 1955): este proceso desembocó en la conformación del Nacionalismo mexicano, que estableció la figura del mestizo como punto de origen y sentido de la mexicanidad durante la época moderna.

Ese desplazamiento o sustitución del Nacionalismo criollo por el Nacionalismo mexicano tuvo en las manifestaciones poéticas, narrativas más concretamente, una expresión representativa del desarrollo de ese 
definitiva solo hasta finales del siglo XIX, en el prólogo de autor del altamiranista José López Portillo y Rojas a La parcela (1898). Ahora bien, lo interesante del planteamiento es que se concibe la historia no necesariamente como un recuento más o menos lógico de sucesos y personajes, sino, más importante, como el reconocimiento de acciones colectivas a través del tiempo, determinantes de la configuración de un entorno socio-cultural particular y del desarrollo de costumbres, valores, temperamentos, conductas, idiosincrasias y perfiles propios con los cuales se identifica y cohesiona el pueblo:

Durante ese largo periodo de tres centurias [que fue la Colonia], cuyo interés creemos haber indicado [antes y el cual reconocemos], después de la conspiración del marqués del Valle, [realmente] escasean los acontecimientos notables y dramáticos que dan lugar a pintorescas y vivas tradiciones, y que se graban en la memoria de un pueblo, sin borrarse jamás. Pueblos que no tienen vida propia no tienen historia; sus acontecimientos son figuras secundarias destinadas a aparecer en último término en otro cuadro [en el del país dominador]. (Zarco 1855: 4, las cursivas son mías)

Coincido con Carlos Aguirre Anaya (2000) al afirmar que el planteamiento de Zarco es, sin duda, contradictorio, pues no proyecta ni asume la historia como proceso siempre perfectible en los planos humano y social, en evolución constante a partir de la dialéctica del presente con el pasado, al menos tal como lo proponían los románticos alemanes, Hegel sobre todo. Por el contrario, el proyecto de Zarco concibe el devenir en términos de mera superación o cancelación, por negación, de procesos o etapas anteriores, como si códigos, valores y representaciones del pasado prehispánico o colonial no pervivieran -transculturados eso sí- en el presente posindependentista del enunciado artístico. Se ha intentado describir y explicar este planteamiento o mecanismo de significación histórica como producto de las dinámicas culturales y de desarrollo implementadas en México durante el periodo colonial, cuando la sustitución de modelos y paradigmas pudo haber sido el mecanismo para consolidar el nuevo esquema del mundo y de relaciones socio-históricas y culturales que provocó la conquista y colonización ( $c f$. Brading 2004) -aunque a la postre dio origen al fenómeno de transculturación cultural y literaria-. Sin embargo, en el marco de este trabajo no es mi intención enzarzarme en resolver esa cuestión, solo apuntarla para destacar el hecho de que, en este tenso y contrastante horizonte conceptual, Francisco Zarco reconoce y otorga a su texto bivocal en particular, a la colección de paisajes y monumentos en general, la función y sentido ético y estético de contribuir en la articulación de una historia, de un perfil, de una identidad propias. Así, luego de reconocer, patéticamente, que México es “ ¡un pueblo sin monumentos!” y, por lo tanto, sin ruinas o testimonios monumentales de su pasado porque el narrador no puede asumir ni entender como propias las realizaciones del mundo prehispánico ni las del periodo colonial, "Fortún" señala como al caso que:

proceso, pues la literatura mexicana estuvo dominada por el protagonismo del criollo durante ese transcurso que podría fijarse entre 1816, año de publicación de El periquillo sarniento, de Fernández de Lizardi, y 1869 , cuando se publica Clemencia, de Ignacio Manuel Altamirano, que instaura de manera contundente la figura del mestizo como el protagonista y mejor exponente de la mexicanidad. 
Lo que hay aquí que describir vale más que las masas de piedra. Ahí está el Popocatépetl coronado de nieve; allí las serranías erizadas y salvajes; allí los jardines que halagan a un tiempo la primavera y el otoño en la Tierra-caliente; en otra región llanuras inmensas, costas fértiles bañadas por el mar que apenas las acaricia con amor; bosques vírgenes, sabinos y ahuehuetes que nacieron el día de la creación... Aquí se estudia la obra de Dios, que es más grande que la de los hombres. (Zarco 1855: 4-5, las cursivas son mías)

Como puede advertirse, México y sus alrededores describe la naturaleza mexicana al más puro estilo romántico planteado por Víctor Hugo en su fundamental "Prefacio" a Cromwell (1827), al concebirla como una realidad que debe su riqueza y armonía gracias al proyecto espléndido y sublime del Todopoderoso. En ese grandioso marco divino se ubican y delinean las "sublimes catedrales y magníficos palacios; [los] galanos acueductos y hospitales; [los] colegios y prisiones; [las] plazas y fuentes" (Zarco 1855: 5) que pueblan y enriquecen a la Ciudad de México. Sin embargo, lo más importante, el artificio ético y estético que solo la hermandad, la relación transversal de la literatura y la litografía pudo resolver, fue que esa serie de descripciones que representan la calidad artística y la magnificencia de las edificaciones, fuentes y plazas, se visualizan siempre en medio del pródigo marco que supone el entorno mexicano, integradas franca y espontáneamente

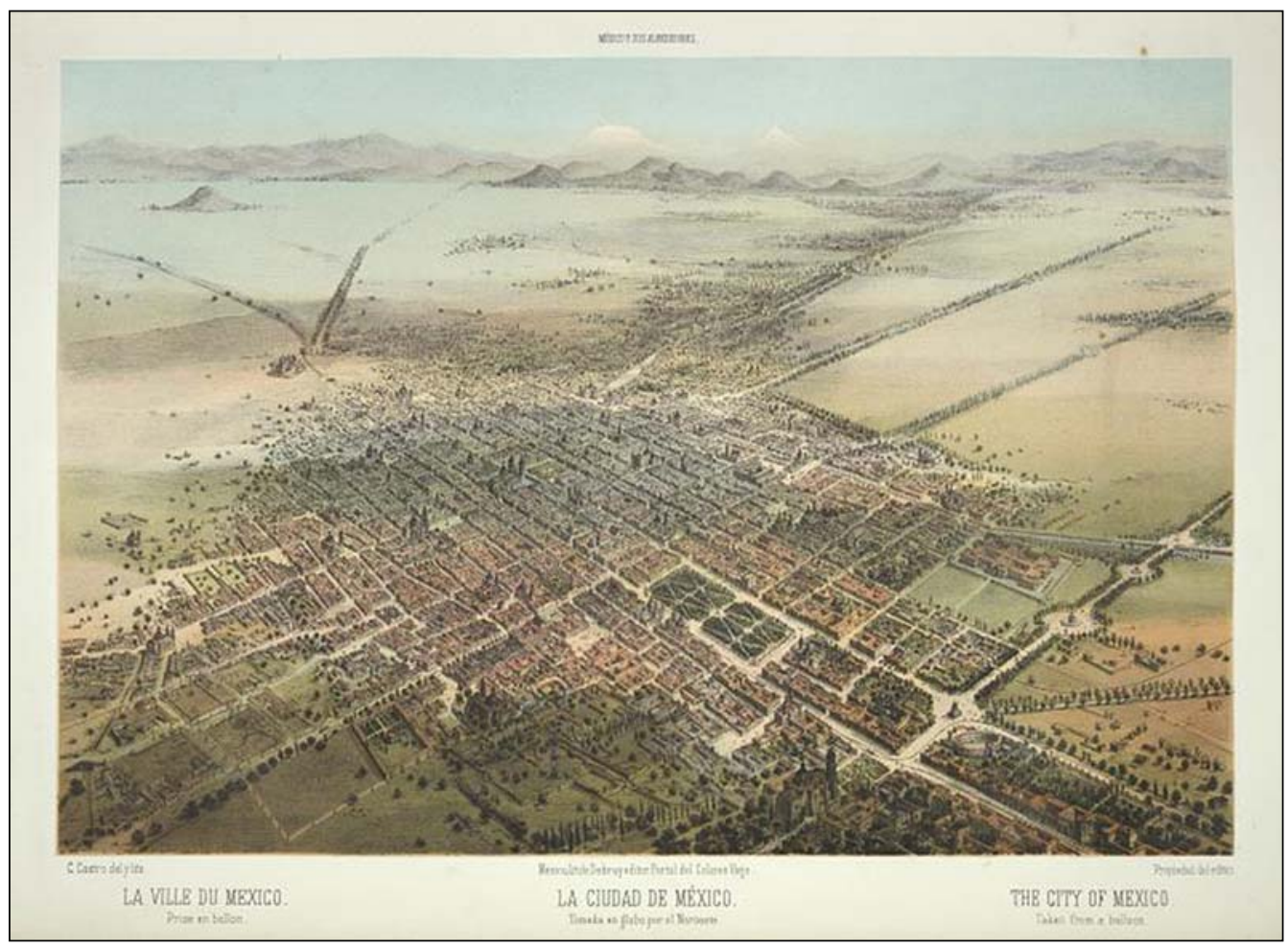

Fig. 9 "La Ciudad de México tomada en globo desde el noroeste". Fuente: México y sus alrededores (1869). Reproducidas con base en las normas de uso de The New York Public Library. 


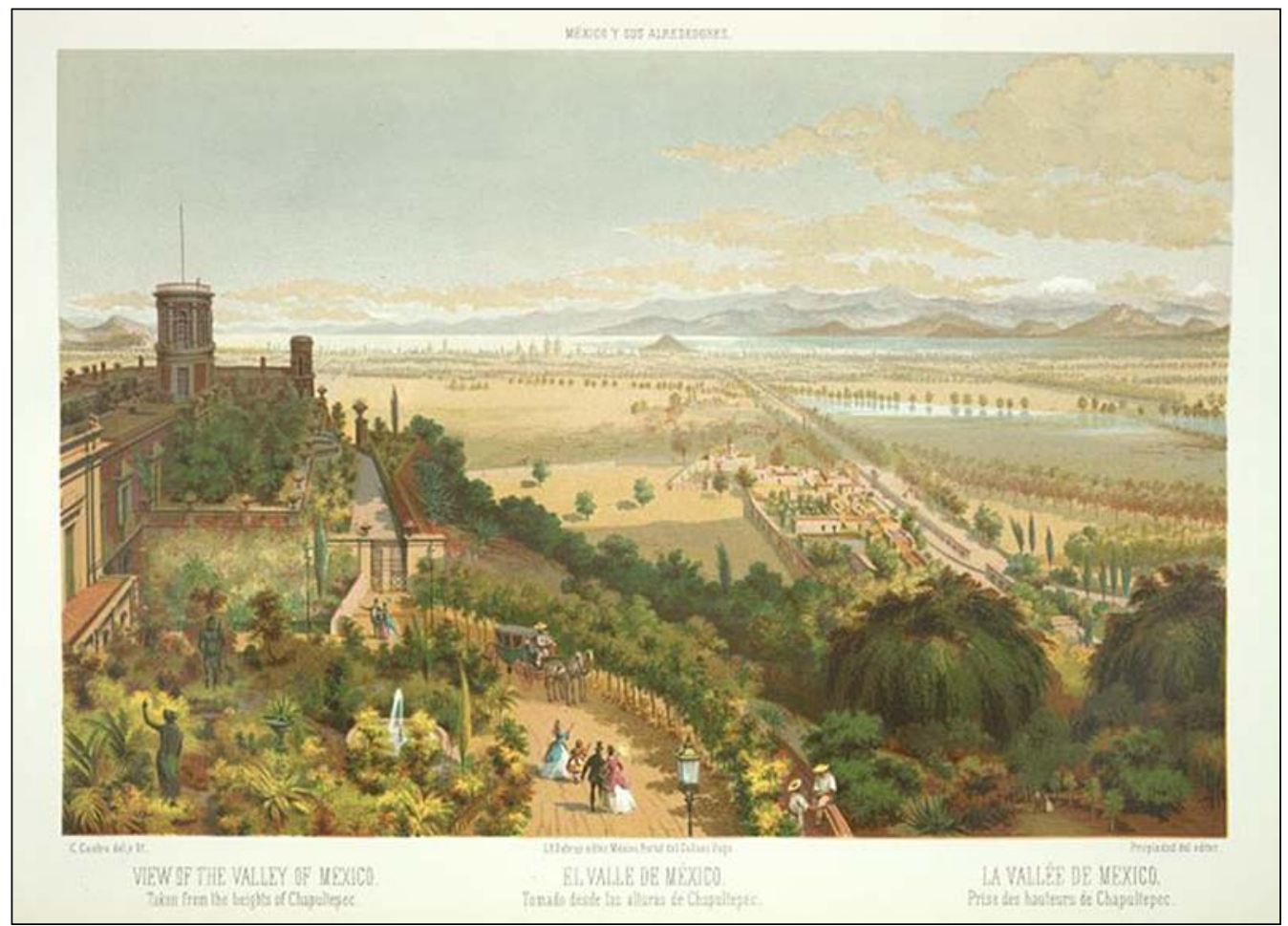

Fig. 10 "El valle de México tomado desde las alturas de Chapultepec". Fuente: México y sus alrededores (1869). Reproducidas con base en las normas de uso de The New York Public Library.

a esa naturaleza propia, gracias a la perspectiva aérea, elevada del pintor, en una especie de condicionamiento del medio natural sobre la cultura. Siguiendo la lógica del enunciado, la colección contribuye a conformar un espacio-tiempo cultural e histórico mexicano, a partir de establecer una contigüidad fundacional entre el proyecto divino que es la naturaleza mexicana y los monumentos y edificaciones que lo pueblan.

Es de destacar el planteamiento de Francisco Zarco en "La fuente del Salto del Agua", el cual condujo a Joseph Decaén, coordinador e impresor del proyecto, a abrir el volumen precisamente con ese artículo. A la vez que se apropia la tradición previa de las colecciones de paisajes y monumentos realizadas en y sobre México -tanto a nivel temático como técnico-, "Fortún" realiza una serie de puntualizaciones que replantean muchas de las características y funciones establecidas para el subgénero en el mundo hispánico por España artística y monumental (1842-1850).

Como dije en el primer apartado de este artículo, gracias a la revista cultural y literaria España Pintoresca, Artística, Monumental, Literaria y de Costumbres (1843-1844), en México se conocía el texto que en París habían comenzado a publicar Jenaro Pérez de Villamil y Patricio de la Escosura, el titulado España artística y monumental. Vistas y descripciones de los sitios y monumentos más notables de España. Con ello se inauguró la tradición costumbrista de las colecciones de paisajes y monumentos en el mundo hispánico, como también, más importante quizás, los letrados y artistas mexicanos se apro- 


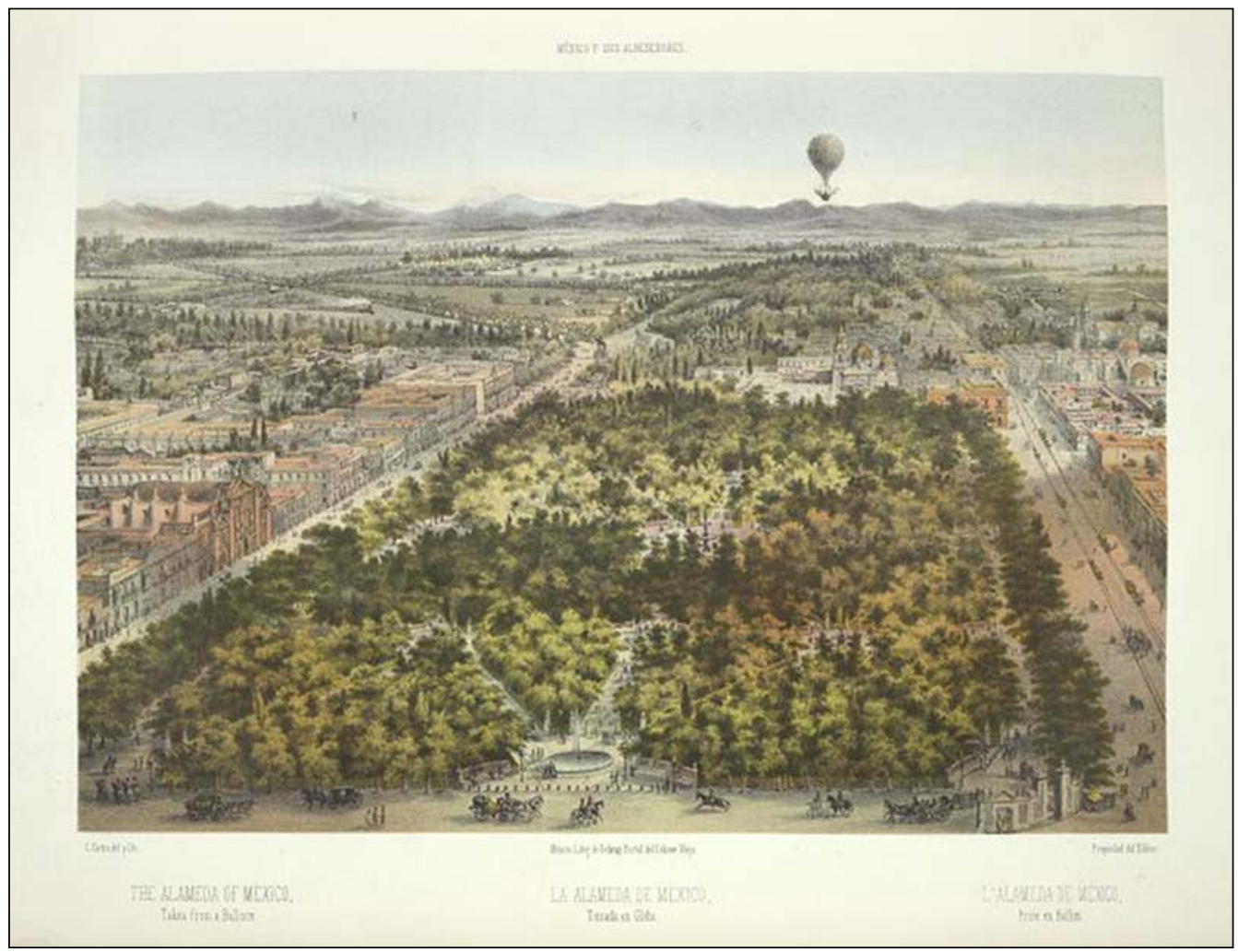

Fig. 11 "La Alameda de México tomada en globo". Fuente: México y sus alrededores (1869). Reproducidas con base en las normas de uso de The New York Public Library.

piaron de las presuposiciones conceptuales a partir de las cuales se le daba significado histórico y cultural a tales representaciones bivocales de paisajes y monumentos: este hecho ayudaría a explicar la fulminante entronización de las colecciones de paisajes y monumentos por sobre las de tipos y escenas costumbristas entre 1843 y 1850.

De esta manera, mientras que el pintor Pérez de Villamil y el narrador De la Escosura -artistas pintoresquistas miembros de la tertulia de "El parnasillo"- habían establecido ya dentro de la tradición hispánica las colecciones de monumentos arquitectónicos, Francisco Zarco por su lado -y con él los demás artistas literarios y plásticos que colaboraron en México y sus alrededores y en tantos otros textos que aparecieron publicados entonces-, a partir de entablar un debate directo aunque tácito con esos presupuestos, replanteó totalmente el sentido de los textos bivocales de paisajes y monumentos. Mientras que los artistas españoles veían en la plasmación literaria y plástica de las grandiosas edificaciones una serie de elementos que podían ayudar a definir el perfil histórico de una cultura y hombre específicos, para los artistas literarios y plásticos mexicanos, en cambio, los monumentos en sí, aparte de la descripción artística, no podían tener más que un débil interés local; referían a tradiciones aisladas, a hechos de escasa importancia que no involucraban a toda la colectividad (Zarco 1856: 5). Igualmente, los creadores mexicanos consideraban que esos vestigios arquitectónicos revelaban el grado de desarrollo 


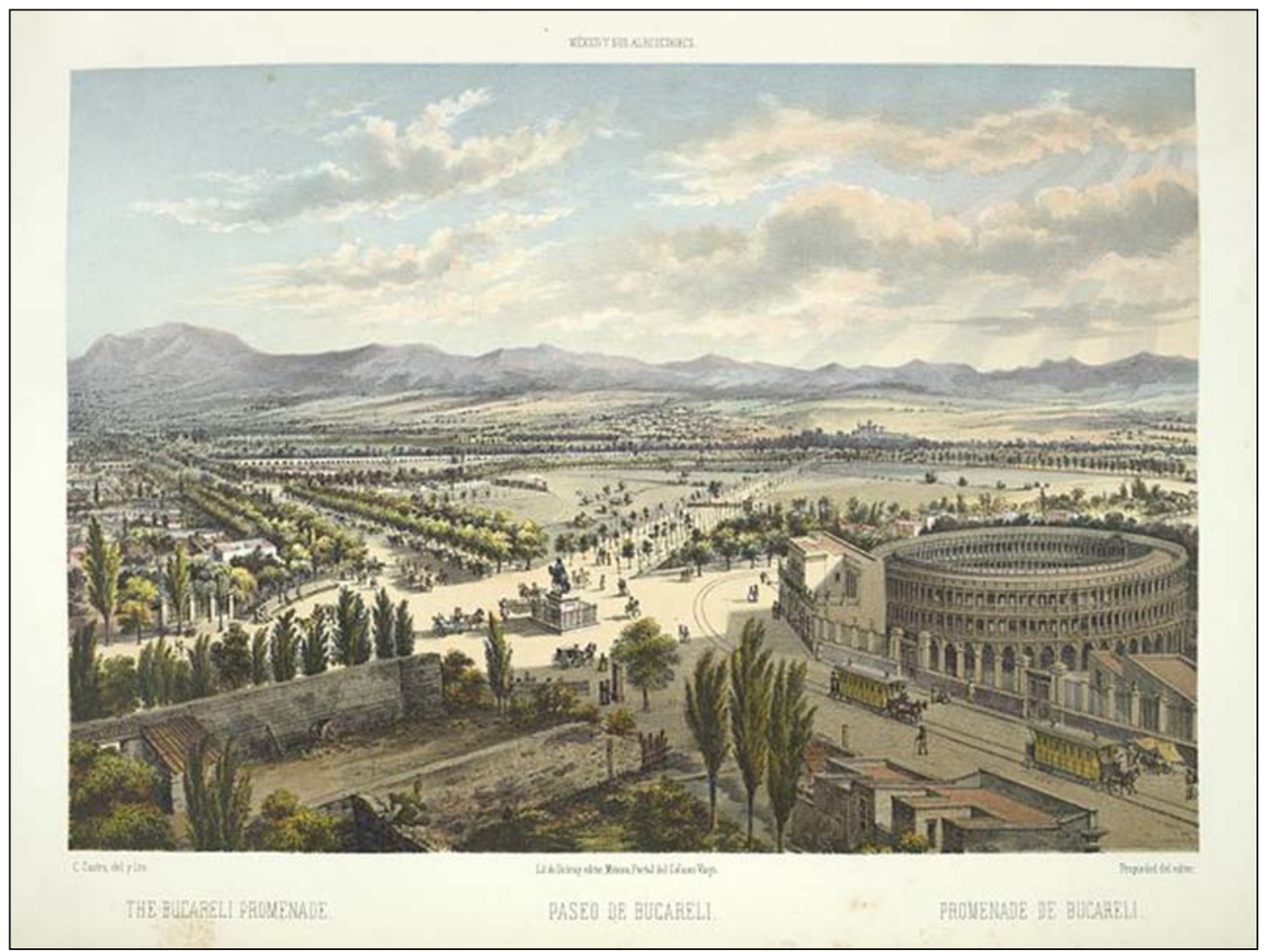

Fig. 12 "El Paseo de Bucareli". Fuente: México y sus alrededores (1869). Reproducidas con base en las normas de uso de The New York Public Library.

de una sociedad y cultura que no era el México independiente y mestizo, sino la Nueva España colonial o la gran Tenochtitlán del mítico azteca. Ahora bien, para que esas edificaciones cobraran un sentido semiótico trascendente, es decir, para que fueran capaces de decir algo a los lectores nacionales contemporáneos, los artistas literarios y plásticos mexicanos propusieron que los monumentos se visualizaran y leyeran no en sí, no en su individualidad artística y arquitectónica, sino en el conjunto de la naturaleza mexicana. Así ubicados serían capaces de generar no solo alcances en lo artístico, sino también en las dimensiones más significativas de lo histórico y lo cultural. Se trata de un principio que tiene su correlato en las resoluciones plásticas que obligan a los litógrafos a dar el mismo nivel de importancia pictórica tanto a las edificaciones como a los límpidos y tenues cielos mexicanos, a las verdes serranías, a los fúlgidos lagos y a los vetustos volcanes que enmarcan a la Ciudad de México.

De esta manera, pues, gracias al debate tácito con los presupuestos en los que España artística y monumental la había fincado, México y sus alrededores. Colección de vistas, monumentos, paisajes y trajes del país otorgó un nuevo sentido ético y estético de la tradición de las colecciones de paisajes y monumentos en México, incorporando de manera dialéctica y protagónica el espacio-tiempo, la naturaleza mexicana determinante de la cultura e índole nacional. 
Particular acierto ético y estético fue la capacidad de escritores y litógrafos del álbum no solo para concatenar la grandiosidad sublime de la naturaleza y las edificaciones mexicanas y el carácter del pueblo, sino para reproducir en todo su dinamismo y dialéctica la existencia cotidiana de la colectividad: así lo prueban vistas y cuadros como "La calle de Roldán y su desembarcadero", "El paseo de la Viga", "El palacio nacional de México" o "Trajes mexicanos". Como señalé antes al leer e interpretar los textos bivocales de Pedro Gualdi, la tradición de las colecciones de paisajes y monumentos en México incorporó como uno de sus elementos composicionales protagonistas no solo los grandes edificios o paisajes, sino también al pueblo diverso que, a pesar de su heterogeneidad sociocultural (o quizás por ella), expresaba una forma de ser, un temperamento, una sensibilidad, un perfil propios. Así lo señalan Marcos Arroniz en el texto bivocal titulado "La Fuente de la Tlaxpana" -con litografía de Castro-, Florencio María del Castillo en "El Paseo de las Cadenas en una noche de luna" -con dibujo de Castro y Rodríguezy "El Paseo de la Viga" -ilustrado por Castro y Campillo-, Francisco González Bocanegra en "La Calle del Puente de Roldán y su desembarcadero" - con lámina de Castro y Campillo-, entre otros enunciados.

En particular quiero comentar el texto literario titulado "El Paseo de Bucareli", en el cual, después de describir las características físicas y las prácticas culturales a que dio origen el paseo citadino, José Tomás de Cuéllar centra su atención en la monumental y ya extinta plaza de toros de San Pablo. Luego de enunciar un tanto técnicamente sus características, el fundador de la novela costumbrista mexicana concentra su atención no en las características de la rambla ni en las de la arena, sino en las del conjunto humano que confluye en el coso. Es interesante advertir que pese a manifestar un contundente rechazo a la corrida de toros, el narrador señala que:

Allí es donde las hermosas, lujosamente engalanadas y colocadas en cada lumbrera, como ramos de flores escogidas, cediendo á la costumbre que nos legaron los españoles, al par que los galanes y los grandes personajes, contemplan con ávida ansiedad, al éco tal vez de las más tiernas creaciones de Bellini y Donizetti, esas escenas de horror, esos lances terribles de la tauromaquia, sangre, terror, muerte y puñaladas.

Y allí es también donde el pueblo, "el público de sol”, entregado enteramente á la contemplación del espectáculo, se le ve agitarse como las olas del océano, se le mira enagenado, absorto, en uno de los lances atrevidos, se escucha el prolongado rumor de sus burlas descaradas, ó nos estremece el grito unánime de aplauso, ó el ¡ay! profundo de compasión, si algún torero fué la víctima. El populacho y la sociedad elegante están frente á frente, separados por su fortuna, y unidos por un mismo instinto, llamados por una misma voz, impulsados por un mismo deseo, el de sentir algo que conmueva, que hiera el corazón, que haga olvidar el rudo trabajo ó la monotonía y el fastidio de toda la semana. (Cuéllar 1855: 22, las cursivas son mías)

De esta manera, pues, el texto bivocal escrito por Cuéllar y dibujado por Casimiro Castro no solo representa las características físicas e históricas de la ronda construida por el virrey Bucareli en 1778 -conocido entonces como "Paseo Nuevo"-, sino, más importante quizás, tiene la sensibilidad de captar el fluir contradictorio de la vida 
en México y del mexicano ${ }^{14}$. En el mismo tenor se había manifestado ya Marcos Arroniz en "La Fuente de la Tlaxpana", quien luego de describir el surtidor y el conjunto humano que confluye en él, señala que ese conjunto formado por naturaleza-monumento-pueblo diverso lo único que revela es que "todo, todo presenta [la] vida, [el] movimiento y [la] alegría [de México y el mexicano]" (1855: 6).

Por estas particularidades considero que, a diferencia de otros ejercicios plásticoliterarios semejantes -como el Microcosmos de Londres (1808), de Rudolph Ackermann, o España artística y monumental (1842-1850)-, México y sus alrededores es a la vez muestra y cima dialéctica de las posibilidades ética y estéticas que la resolución de las colecciones de vistas de paisajes y monumentos tuvo en la tradición cultural, artística y literaria mexicana.

\section{A MANERA DE CONCLUSIÓN}

Hasta aquí, luego de plantear su relación con el surgimiento de las principales obras literarias de la tradición occidental, he tratado de mostrar cómo el motivo del viaje determinó la composición de las colecciones de paisajes y monumentos, mismas que fueron una de las resoluciones artísticas más notables de la centuria decimonona. Gracias a la interrelación transversal de literatura y litografía, la cultura romántica del siglo XIX articuló un discurso, unas imágenes y unos valores escriturarios e icónicos definitorios para las sociedades nacionales emergentes, particularmente para México. En tal contexto, traté de mostrar que primero vía los planteamientos bivocales de artistas extranjeros -como Linati, Nebel, Waldeck, Egerton, Rugendas-, luego con la apropiación y praxis de la técnica por parte de los artistas nacionales, se desarrolló y consolidó rápidamente una tradición propia que tuvo en México y sus alrededores no solo el clímax, sino el modelo a seguir: como traté de explicar, la colección diseñada y coordinada por Joseph Decaén replanteó los presupuestos que justificaban y daban sentido histórico y cultural a las colecciones de paisajes y monumentos dentro de la tradición hispánica, al crear un sentido histórico no a partir de los monumentos o edificaciones en sí, sino a partir de su comprensión dentro del entorno natural que los determina.

Poco más puedo agregar a lo dicho, salvo la consideración de que es necesario recuperar las resoluciones artísticas concretas, así como repensar los procesos de significación artística desarrollados durante la centuria decimonona en México, pues con ese ejercicio revisor podremos comprender un poco más la diversidad de elementos y la complejidad de las interrelaciones que han dado sentido y han condicionado las características de nuestro ser actual.

\footnotetext{
14 Si bien hay dos ediciones de esta lámina (la de 1855 y la de 1869, aunque con el mismo ángulo y perspectiva), el texto literario se mantiene invariante al enfocar su esencia en el reconocimiento del temperamento e idiosincrasia nacionales.
} 


\section{BIBLIOGRAFÍA}

Aguilar Ochoa, Arturo (2007) "Los inicios de la litografía en México: el periodo oscuro (1827-1837)”. Anales del Instituto de Investigaciones Estéticas. 29 (90): 65-100.

Aguirre Anaya, Carlos (2000) "Introducción". México y sus alrededores. Colección de monumentos, trajes y paisajes. México, Breve Fondo Editorial: 16-36.

Anónimo (1843) “Introducción”. En: España Pintoresca, Artística, Monumental, Literaria $y$ de Costumbres. I: 3-10.

Arroniz, Marcos (1855-1856) “La Fuente de la Tlaxpana”. En: Joseph Decaén (ed.) México $y$ sus alrededores. Colección de monumentos, trajes y paisajes dibujados al natural. México, Imprenta de Joseph Decaén: 6.

Benavides, Carolina (2007) "Actores, escenarios, relaciones sociales en tres publicaciones periódicas mexicanas de mediados del siglo XIX". Historia mexicana. 56 (4): 1163-1199.

Bobadilla Encinas, Gerardo Francisco y Avechuco Cabrera, Daniel (2020) "Palabra, imagen e independencia en la posindependencia y la posrevolución mexicana”. Iztapalapa. 88 (41): 97-129.

Brading, David (1997) Los orígenes del nacionalismo mexicano. México, Editorial Era. ----- (2004) Mito y profecía en la historia de México. México, Fondo de Cultura Económica. DecaÉn, Joseph, ed. (1855) México y sus alrededores. Colección de monumentos, trajes y paisajes. México, Imprenta de Joseph Decaén.

(1869) México y sus alrededores. Colección de monumentos, trajes y paisajes. México, Imprenta de Joseph Decaén. https://digitalcollections.nypl.org/collections/mxico$\mathrm{y}$-sus-alrededores-coleccion-de-vistas-monumentales-paisajes-y-trajes-del\#/?tab= about [16.10.2019].

Castro, Miguel Ángel y Curiel, Guadalupe (2005) Publicaciones periódicas mexicanas del siglo XIX. 1822-1855. México, Universidad Nacional Autónoma de México.

Cuéllar, José Tomás de (1855) "El Paseo de Bucareli”. En: Joseph Decaén (ed.) México $y$ sus alrededores. Colección de monumentos, trajes y paisajes dibujados al natural. México, Imprenta de Joseph Decaén: 22-23.

GuAldi, Pedro (1981) Monumentos de México tomados del natural. México, Fomento Cultural Banamex.

Gunia, Inke (2008) De la poesía a la literatura: el cambio de los conceptos en la formación del campo literario español del siglo XVIII y principios del XIX. Madrid, Editorial Iberoamericana.

López, Urbano (ca. 1850) Álbum pintoresco de la República Mexicana. México, Estampería de Michaud y Thomas. http://bdh-rd.bne.es/viewer.vm?id=0000135129\&page=1 [23.10.2019].

Martínez, José Luis (1955) La emancipación literaria de México. México, Antigua Librería Robredo.

Ocampo, Liliana Astrid (2012) "La Ciudad de México en las litografías de Casimiro Castro, 1855-1864”. Bacoa. Revista Interdisciplinaria de Ciencias y Artes. 2: 62-81. 
Ortega Fernández, Isabel (2010) "La pieza del mes. «San Pablo de Valladolid», de Jenaro Pérez de Villamil”. En: Catálogo del Museo del Romanticismo. Madrid, Museo del Romanticismo: 1-23.

PaYno, Manuel (2007) Artículos y Narraciones. México, Universidad Nacional Autónoma de México.

Perales, Alicia (1955) Asociaciones literarias mexicanas. Siglo XIX. México, Universidad Nacional Autónoma de México

PéreZ de Villamil, Jenaro y de la Escosura, Patricio (1842) España artística y monumental. Vistas y descripción de los sitios y monumentos más notables de España. T. I. París, Editorial de Alberto Hauser.

PÉREZ SALAS, María Esther (2009) "Nuevos tiempos nuevas técnicas: litógrafos franceses en México (1827-1850)”. En: Impresiones de México y de Francia. México, Éditions de la Maison des sciences de l'homme - Instituto Mora: 219-254.

----- (2017) “Imágenes de poder: claustros, cúpulas y campanarios”. En: Miguel Ángel Castro (ed.) El viajero y la ciudad. México, Universidad Nacional Autónoma de México: 103-117.

Ruiz Castañeda, María del Carmen (1995) “Introducción”. En: El Recreo de las Familias. México, Universidad Nacional Autónoma de México: XI-LVIII.

SPELL, Jefferson Rea (1938) "El movimiento costumbrista mexicano". Revista Universidad. (2): 5-11.

Urrejola, Bernarda de (2011) "El concepto de literatura en un momento de su historia: el caso mexicano, 1750-1850". Historia Mexicana. 3 (239): 1683-1732.

Zarco, Francisco (1855) "La Fuente del Salto del Agua". En: Joseph Decaén (ed.) México $y$ sus alrededores. Colección de monumentos, trajes y paisajes. México, Imprenta de Joseph Decaén: 4-6. 